\title{
Medieval recipes about toothpastes by Abulcasis
}

\section{Prof. Dr. Luisa Maria Arvide Cambra}

\author{
University of Almeria, Spain. \\ Imarvide@ual.es
}

\begin{abstract}
Abulcasis Al-Zahrāwī (c.936-c.1013) is a very important physician of Al-Andalus, besides an eminent surgeon, the first one of Medieval Islam. His main work, titled Kitāb al-Tașrīf (Book of medical arrangement), contains in its $19^{\text {th }}$ treatise, which deals with cosmetics and drugs for health and embellishment of body, interesting recipes of a great value to the diverse scientific fields, such as the pharmacology, dentistry dermatology, cosmetics and aesthetic medicine. This article is an approach to the study of the treatise above mentioned, and includes the translation from Arabic to English of some recipes about toothpastes, according to the 5774th Arab manuscript of the National Library at Paris.
\end{abstract}

Keywords: Abulcasis Al-Zahrāwī, Kitāb al-Tașrīf, Medieval Arabic Science, Dentistry, Aesthetic Medicine

\section{INTRODUCTION}

The Cordovan Abulcasis Al-Zahrāwī (c.936-c.1013) [1] is one of the most important physicians of Al-Andalus, besides an eminent pharmacist and surgeon, the first one of Medieval Islam [2].

The importance of Abulcasis is restricted not only to the history of Arabic science [3], but also to the history of the universal scientific knowledge, due to his influence in the European scientists until early the $17^{\text {th }}$ century [4].

In the field of pharmacology, which this article mainly is about, Abulcasis is certainly one of the most outstanding representatives of Islamic science, for his achievements in pharmacy and pharmacopoeia [5]; and in the field of dentistry, which this paper also deals with, he takes a high place, for his advances and discoveries, such as the dental filling technique he already used late the $10^{\text {th }}$ century and early the $11^{\text {th }}$ century [6].

The $19^{\text {th }}$ treatise of his main work, titled Kitäb al-Tașriff (Book of medical arrangement), deals with cosmetics and drugs for improvement and embellishment of body [7]; and, among other things, it contains in the $5^{\text {th }}$ chapter interesting recipes for health and dental care of a great value to both the fields of pharmacology and dentistry, as well as to aesthetic medicine.

\section{The $19^{\text {th }}$ treatise from the Kitāb al-Tașrīf}

The Kitāb al-Tași $f^{\prime}$ 's $19^{\text {th }}$ treatise is contained in folios $74 v^{0}-92 \mathrm{r}^{\mathrm{o}}$ of the $5774^{\text {th }}$ Arabic manuscript from the National Library at Paris. It is an interesting manual of both aesthetic medicine and cosmetics about perfumes, drugs and remedies for the body health as well as for its improvement and embellishment.

Reading this handbook allows to reconstruct the aesthetic canons of Arab society in the late $10^{\text {th }}$ and early $11^{\text {th }}$ centuries, as well as indicates the interest showed by this society in hygiene, beauty, ornament and perfume, and how these factors are closely connected to body health, characteristics all of them still in force in today's society, eleven centuries later. For example, then the tooth whitening was so recognized, and so excellent toothpastes and other remedies for getting whiter teeth are described.

This treatise has great pharmacological value and is divided into two sections:

Section I: About perfumes. It is divided into ten chapters. 
Section II: About drugs and remedies for the body health as well as for its improvement and embellishment. It is also divided into ten chapters.

The $5^{\text {th }}$ chapter of the section II (folios 86 r- $^{\circ} \mathrm{f}^{\mathrm{o}} \mathrm{8} 8 \mathrm{r}^{\mathrm{o}}$ ) ) is about drugs and remedies for health and dental care, and includes seventeen medieval recipes, valuable for history of pharmacology and dentistry. This chapter, as the rest of the book, incorporates many quotes to other outstanding authors, such as Ishāq b. 'Imrān (tenth century) [8], Al-Rāzī (865-925) [9], Ibn Māsawayh (d.875) [10]; etc.

The translation to English of some recipes about toothpastes, according to the 5774th Arabic manuscript of the National Library at Paris, can be seen below.

\section{Recipes of toothpastes for health and dental care}

1. Recipe of a toothpaste to whiten teeth and perfume breath [ $\left.\mathrm{f}-87 \mathrm{r}^{\circ} \mathrm{o}\right]$

You take borax, halcyon and rock salt, from each, 1 mithqāl; and 1/2 mithqāl of saffron. You crush everything and use it as a toothpaste. This remedy certainly cleanses and whitens teeth, and also perfumes breath.

\section{Recipe of pills to whiten teeth and perfume breath [ $\left[\mathrm{f}-87 \mathrm{v}^{\mathrm{0}}\right]$}

You take peeled China ginger, dried grapefruit peels, camphor and saffron, from each, 3 dirhams. You crush everything, knead it with rose water, and with this make some pills same size as chickpeas. The pills are left to dry in the shade, then you take and use them, if the Almighty wants.

3. Recipe of a toothpaste written by Ishạq $b$. 'Imrān to clean and whiten teeth as well as to perfume breath, and prevent and stop pyorrhea [ $\left.\mathrm{f}^{\mathrm{o}} 87 \mathrm{v} \mathrm{0}\right]$

You take rock salt mixed with honey burnt and later slaked with rose water, and also barley flour kneaded with wine and slaked with rose water, from each 20 dirhams; 10 dirhams of halcyon; 5 dirhams of Chinese cinnamon, licorice, sukk, and sedge; 3 dirhams of Indian wood, pomegranate flowers and myrrh; and 2 dirhams of clove, fennel and Indian spikenard. You crush everything, sieve it and use it as a toothpaste. For those who have a hot physical constitution, it can be added 1 dirham of camphor, and this will be beneficial.

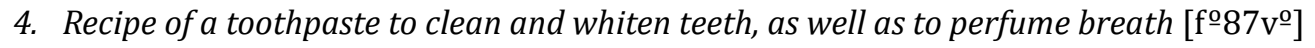

You take burnt myrobalan, snail burned, burnt vine sticks and burnt goat hoofs, from each, 4 mithqāls; alcyon, faience and pumice, from each, 3 mithqāls; burnt deer horn, burnt date pit and bamboo manna, from each, 2 mithqāls; and rāmik, pomegranate flowers, rose seed and sumac, from each, 1 mithqāl. You crush everything, knead it and use it as a toothpaste in the morning. This extraordinarily whitens teeth, God willing.

\section{Recipe of a toothpaste to clean, whiten and polish teeth, as well as to remove dental stains [f은 $\left.8 \mathrm{v}^{\mathrm{o}}\right]$}

I [Abulcasis] have already tested. You take faience, nitre burned, burnt cow hoof bone, burnt goat horn and coral burned, from each, 10 dirhams; 5 dirhams of pumice; 3 dirhams of licorice; 2 dirhams of pomegranate; and 1 dirham of spikenard, nitre, Yemeni alum and costus. You crush everything, sieve it and use it as a toothpaste. It is beneficial, God willing.

\section{Glossary: Weights, measures and remedies}

1 Dirham= 3,12 grams

\section{Mithqāl= 4,68 grams}

Rāmik, in Arabic: It is a medicine made up dye gall, raisins, myrobalan and olive oil. If musk is added, it is named as Sukk. 


\section{Conclusion}

The pages translated in this article exemplify the high level achieved by Arab scientific knowledge in the Middle Ages, and certify the importance of Abulcasis Al-Zahrāwī in the history of Islamic science. His work Kitāb al-Tașif is in a high-ranking place within surgery, medicine and pharmacology of Al-Andalus. For the influence exercised in Europe until the early $17^{\text {th }}$ century, among other reasons, Abulcasis has a very relevant position in the history of both universal culture and science.

\section{REFERENCES}

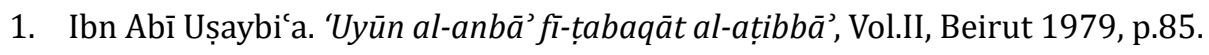

2. Arvide Cambra, Luisa Maria. "Abulcasis Al-Zahrawi, The Surgeon of Al-Andalus", European Scientific Journal, May 2016, Special edition, 240-247 (Proceedings $2^{\text {nd }}$ Pan-American Interdisciplinary Conference, PIC 2016, Buenos Aires, Argentina, 24-26).

3. Ullmann, Manfred. Die Medizin im Islam, Leiden 1970, pp.128-136.

4. Levey, Martin. Early Arabic pharmacology. An introduction based on ancient and medieval sources, Leiden 1973.

5. Mieli, Aldo. La science arabe et son rôle dans l'évolution scientifique mondiale, Leiden 1966.

6. Arvide Cambra, Luisa Maria. Tratado de odontoestomatología en Abulcasis, Almería, University Press, 2003.

7. Arvide Cambra, Luisa Maria. Tratado de estética y cosmética en Abulcasis, Granada 2010.

8. Leclerc, Louis. Histoire de la médecine árabe, Vol.I, Paris 1876, pp.408-409.

9. Brockelmann, Carl. Geschichte der arabischen Litteratur, Vol.I, Leiden 1937, p.233.

10. Sezgin, Fuat. Geschichte des arabischen Schrifttums, Vol.III, Leiden 1975, pp.231-236.

Citation: Luisa Maria Arvide Cambra, "Medieval recipes about toothpastes by Abulcasis". American Research Journal of English and Literature, vol 6, no. 1, 2020, pp. 1-3.

Copyright (c) 2020 Luisa Maria Arvide Cambra, This is an open access article distributed under the Creative Commons Attribution License, which permits unrestricted use, distribution, and reproduction in any medium, provided the original work is properly cited. 